\title{
Persistent and emerging micro-organic contaminants in Chalk groundwater of England and France
}

\author{
Lapworth DJ ${ }^{1 *}$, Baran $\mathrm{N}^{2}$, Stuart $\mathrm{ME}^{1}$, Manamsa $\mathrm{K}^{1}$, Talbot $\mathrm{J}^{1}$ \\ ${ }^{1}$ British Geological Survey, Maclean Building, Wallingford, Oxfordshire, OX10 8BB, UK \\ ${ }^{2}$ Bureau de Recherches Géologiques et Minières, 3 Avenue Claude Guillemin, BP 6009, \\ 45060 Orléans Cedex 2, France \\ * Corresponding author: djla@bgs.ac.uk
}

\section{Highlights}

- Broad range of microorganics detected in Chalk groundwater in England and France

- Plasticisers, pesticides, BPA and THM detected at the highest concentrations

- Pesticides higher in outcrop Chalk, caffeine and BPA at concealed sites

- Occurrences show some relationship to land use, borehole depth and water level 


\begin{abstract}
The Chalk aquifer of Northern Europe is an internationally important source of drinking water and sustains baseflow for surface water ecosystems. The areal distribution of microorganic (MO) contaminants, particularly non-regulated emerging MOs, in this aquifer is poorly understood. This study presents results from a reconnaissance survey of MOs in Chalk groundwater, including pharmaceuticals, personal care products and pesticides and their transformation products, conducted across the major Chalk aquifers of England and France. Data from a total of 345 sites collected during 2011 were included in this study to provide a representative baseline assessment of MO occurrence in groundwater. A suite of $42 \mathrm{MOs}$ were analysed for at each site including industrial compounds $(n=16)$, pesticides $(n=14)$ and pharmaceuticals, personal care and lifestyle products $(n=12)$. Occurrence data is evaluated in relation to land use, aquifer exposure, well depth and depth to groundwater to provide an understanding of vulnerable groundwater settings.
\end{abstract}

Capsule: Broad screening reveals for the first time the extent of emerging microorganic pollution in Chalk groundwater sources across England and France

Keywords: Groundwater; Microorganics; Pharmaceuticals; Emerging contaminants; Pesticides; Chalk aquifer

\title{
1 Introduction
}

In the last few decades there has been a growing interest in the occurrence of micro-organic (MO) contaminants in the terrestrial and aquatic environment, and in their environmental fate and potential toxicity (Halling-Sørensen et al. 1998, Kolpin et al. 2002, Kümmerer 2009). A large variety of MOs are used in huge quantities for a range of purposes including arable agriculture, industrial manufacturing processes, as well as human and animal healthcare. The contamination of groundwater resources by MOs is a growing concern and relatively poorly 
understood compared to other freshwater resources. While groundwaters often have a high degree of protection from pollution due to physical, chemical and biological attenuation processes in the subsurface compared to surface aquatic environments (e.g. Barnes et al. 2008) it is clear from recent studies that trace concentrations of a large range of compounds including emerging contaminants, that are not currently regulated, are still detected in groundwaters (Focazio et al. 2008; Lapworth et al. 2012, Loos et al. 2010; Lopez-Serna et al., 2013; Stuart et al. 2014, 2012).

The Chalk aquifers of NW Europe are a hugely important natural resource, providing drinking water and sustaining river flows across a large part of southern England and northern France (see Fig. 1), as well parts of as Belgium, Germany, the Netherlands and Denmark. The Chalk is the most significant aquifer in the United Kingdom, providing around $27 \%$ of all drinking water nationally and over $80 \%$ in areas of the south and east of England (UKWIR 2004). In France it provides $15 \%$ nationally and locally up to $80 \%$ (Crampon et al. 2000). The groundwater-fed streams which drain this area support a diverse ecosystem including several internationally recognised special areas of conservation under the Habitats Directive (EC 1992).

The Chalk aquifers of southern England and northern France are located in a region with a long history of dense population and industry, and underlie both of the capital cities. The population density in the UK, particularly in southeast England, is considerably higher than that in northwest France. Due to high population densities non-agricultural contaminant loading is anticipated to be highest in SE England and parts of NW France, a significant part of which is underlain by Chalk; these major aquifers are likely to be some of the most at risk for MO contamination from urban waste water sources.

As a result of a drive for greater agricultural productivity in the post war period, the thin soils which overly the exposed parts of the Chalk aquifers have supported increasingly intensive 
cultivation including cereal production, livestock farming as well as viniculture (Cun and Vilagines 1997; Burt et al., 2011). This move towards intensive farming has led to the use of a wide array of organic compounds for pest and disease control over this period, the natural nutrient-poor status of the soils has also meant that large quantities of fertilisers have been used. As such, for many decades these aquifers have had a high loading of MOs from a range of sources including diffuse arable agriculture, discrete sources such as reticulated sewage systems, effluent from treatment of domestic and industrial wastewater, landfills and septic tanks (Baran et al., 2008; Baxter 1985a, 1985b; Chilton et al. 2005; Foster et al. 1991; Stuart et al., 2014).

The fissured, and in places karstic, nature of the Chalk means that this aquifer can be particularly vulnerable to the rapid vertical and horizontal migration of contaminants (Baran et al. 2008, Gooddy et al. 2002, Johnson et al. 2001, Katz et al. 2009, Lapworth and Gooddy 2006, Morasch 2013). The unsaturated zone thickness can be considerable (>80 $\mathrm{m}$ ) in areas of higher elevation which can lead to pollution attenuation in the unsaturated zone through dispersion and diffusion into the matrix (Foster et al. 1991, Gooddy et al. 2007, Stuart et al. 2011). Once organic contaminants move from the soil to the unsaturated zone the potential for degradation and attenuation is significantly diminished (Johnson et al. 1998). The relationship between the Chalk and the overlying drift deposits are important in controlling hydrogeology and prevailing geochemical conditions (Edmunds et al. 1987; Edmunds and Shand 2008; Kloppmann et al. 1998; Lloyd and Hiscock 1990).

The purpose of this study is to evaluate the occurrence of a broad suite of MOs in untreated groundwater from two large study areas in NW Europe, the Chalk of England and the Chalk of NW France. The differences in occurrence and detected concentrations between these two study areas will be explored, as well as the spatial variations in relation to potentially important factors such as land use, depth to groundwater and the degree of aquifer 
concealment. This study is unique for a number of reasons: i) it provides the first detailed study of pharmaceutical occurrence in the most important groundwater resource in SE England and NW France, which is locally the most important source of drinking water, ii) the Chalk aquifer chosen has a large spatial area and variety of hydrogeological settings, ii) it analysed data from a very large number of sampling sites (>350), iv) it looks at the broad suite of organic compounds (16 industrial compounds, 14 pesticides and 12 pharmaceuticals and personal care compounds).

\section{Methods}

\subsection{Site characterisation and sample collection}

Both study areas were sampled during 2011. Raw groundwater was collected for analysis in both France and England. Particular care was taken during sampling to minimise contamination during sampling and the borehole was purged prior to sampling. The French survey included 45 sites from the Chalk outcrop, for England there were 300 sites. The outline of the Chalk outcrop and the sample network is shown in Fig. 1.

Selected covariates investigated as part of this study included concealment by impermeable cover, land use type, depth of borehole and depth to water. Sites were categorised as "concealed" where impermeable superficial cover was $>10 \mathrm{~m}$ or where the sites were confined by impermeable Palaeogene and Neogene sediments (Fig. 1). Otherwise sites were defined as "exposed". Land use classification was carried out using a 500-m radius search around each site using the most recent CORINE land use data set for Europe (EEA 2006). A simple scheme for land use classification was used by grouping land use into the four main categories within each search radius: (i) Natural land use which included natural grassland and forest; (ii) Urban land use; (iii) Arable agricultural land use and (iv) Pasture/grazing. Each site was then classified by each land use type where $>60 \%$ of the area in the search 
radius corresponded to one of the four categories outlined above. A handful of sites (>5\%) had mixed land use, with equal proportions of two or more land use types, these were excluded from subsequent analysis based on land use. Total borehole depth and depth to water table for each site, minimum depth to water table, was taken from existing national water level monitoring data. For sites in England minimum depth to the water table was estimated using a BGS data from a digital terrain model (DTM), BGS 1:100K hydrogeology maps and point data available in the BGS WellMaster database, for sites in France on site water level measurements were used when available.

\subsection{Analysis and $Q C / Q A$}

Table 1 shows the list of compounds used in this study and selected properties including literature $\mathrm{K}_{\mathrm{ow}}$ values. The list of compounds represents a broad range of different compound groups highly relevant from a water quality perspective; industrial compounds $(n=16)$, pesticide compounds and transformation products $(n=14)$ as well as newly emerging contaminants such as pharmaceuticals and lifestyle compounds $(n=12)$. Groundwater samples from England were collected by the Environment Agency and analysed by their National Laboratory Service (NLS) using a multi-residue GC/MS method which is semi-quantitative and screens for $>800$ organic compounds. For details on analysis and QC/QA see Sorensen et al., (2014).

Groundwater samples collected in France were analysed in two private laboratories, CARSO and Institut Pasteur. Briefly, polar compounds i.e. pharmaceuticals and most pesticides were measured after solid phase extraction and LC-MS/MS analysis relying on the ISO 11369 procedure. Non-polar compounds were measured by GC/MS after a liquid-liquid extraction. Finally some compounds were measured by GC/MS according to the ISO16395 procedure dealing with organophosphorus and nitrogeneous compounds. 
Both French laboratories are accredited according to NF EN ISO 17025 standard. This standard includes quality assurance procedure, method validation, internal quality control (blank, recovery test), participation to proficiency test when available and regular third evaluation. When the method includes an extraction step, results are corrected with extraction yield. The limits of quantification for a large number of substances have been calculated according to AFNOR NF T90-210 standard.

For the English laboratory data results were censored at $0.01 \mu \mathrm{g} / \mathrm{L}$; the limit of quantification was variable depending on the method used for the French data set. Prior to data analysis English and French data sets were combined and censored using the highest method detection limit of either data set, this provided a consistent data set for statistical comparison and interpretation.

\section{Results and discussion}

\subsection{Concentrations and frequency of detections}

Summary statistics, maximum concentration and frequency, of detections for English and French sites are shown in Table 2. Overall the highest concentrations detected were for the plasticiser bisphenol A (100 $\mu \mathrm{g} / \mathrm{L})$, followed by chlordibromomethane $(29 \mu \mathrm{g} / \mathrm{L})$, diethyl phthalate(DEP) $(22 \mu \mathrm{g} / \mathrm{L})$, diethylhexylphthalate (DEHP) $(13 \mu \mathrm{g} / \mathrm{L}), 2,6$-dichlorobenzamide (BAM)(10 $\mu \mathrm{g} / \mathrm{L})$, boscalid $(2.3 \mu \mathrm{g} / \mathrm{L})$, caffeine $(1.7 \mu \mathrm{g} / \mathrm{L})$, oxadixyl $(1.4 \mu \mathrm{g} / \mathrm{L})$ and metronidazole $(1.4 \mu \mathrm{g} / \mathrm{L})$. The top 9 compounds (in term of concentrations) were detected in England, this is perhaps not surprising as there are more results for the English Chalk. In France the maximum concentrations for the majority of MOs detected were much lower with the highest results for chlorodibromomethane $(19 \mu \mathrm{g} / \mathrm{L})$, DEHP $(2.7 \mu \mathrm{g} / \mathrm{L})$ and bisphenol A $(1.4 \mu \mathrm{g} / \mathrm{L})$ and N-butylbenzenesulfonamide $(B B S A)(1.3 \mu \mathrm{g} / \mathrm{L})$. The high concentrations of plasticisers, e.g. bisphenol-A and phthalates, detected are possibly an artefact of plastic or 
resin components of the monitoring point casing or headworks. Thirteen of the 42 compounds were not detected, including cotinine, BBSA, metronidazole and 4 chlorinated solvents. Over half of the compounds (26) were not detected in France including all the phthalates as well as several pesticides (boscalid, dimethenamid and diphenylamine, propiconazole and propyzamide) and pharmaceuticals (ethylparaben, ibuprofen, propylaparaben, triclosan and triclosan-methyl. Diphenylamine is a withdrawn fungicide that was used for apples and pears preservation after harvest. Boscalid is also a fungicide used with a low rate of active substance per hectare. Propizamide is not used in large quantities as Dimethenamid (allowed as dimethenamid-P) which is used to a limited extent on wheat compared to other chloroacetanalides, metolachlor and acetochlor. The limited use of these pesticides in France may explain these observations. Detection frequencies in UK for most of these were also very low, suggesting that these detections relate to isolated point sources related to specific crops with limited spatial distributions.

Total $(\Sigma)$ industrial compound and pharmaceuticals had comparable detection frequencies in France and England, however pesticides were detected in $22 \%$ of samples in England compared to $73 \%$ in France. Overall, desethyl atrazine (DEA) (12.3\%), atrazine $(7.3 \%)$, BAM $(6.3 \%)$ and oxadixyl (4.6\%) were the most frequently detected pesticides in England. Of the pharmaceuticals PCPs and lifestyle compounds (PPCPLs), caffeine (6.3\%) DEET (3\%) and carbamazepine (2.3\%) were the most frequently detected in England, and for industrials chlorodibromomethane (5.3\%), DEP (3\%), Bisphenol-A (2.7\%) and dimethyl phthalate $(2.7 \%)$ were the most frequently detected compounds.

In France DEET was not detected in any of the sites, the most frequently detected pesticidal compounds were DEA (60\%), atrazine (47\%), bentazone (11\%), desisopropyl atrazine (DIA) $(6.7 \%)$ and diuron (6.7\%). For industrial compounds DEHP (31\%) and chlordibromomethane 
(20\%) and bisphenol A (8.9\%) were the most frequently detected. Caffeine (24\%), carbamazepine (13\%) and metronidazole (4.4\%) were the most frequently detected PPCPLs.

Atrazine and its breakdown products DEA and DIA remain the most frequently detected compounds in groundwater in this study despite the withdrawal of atrazine for nonagricultural purposes in the EU two decades ago in 1991and for all uses in 2004, with an extension to 2007 in England. In France, an almost ubiquitous presence of atrazine and DEA in groundwater was previously observed in the limestones of the Jura, Chalk of Parisian Basin or alluvial aquifer (Morasch 2013, Baran et al., 2008, Amalric et al., 2013). Simazine and oxadixyl have also been withdrawn but persist in groundwater; oxadixyl was detected in 4.7\% of samples in England and had comparable frequency (4\%) in France.

Fig. 2 shows censored box plots for total values for groups of compounds, comparing the concentration distributions in England and France. Fig. S1 shows censored box plots for a range of individual compounds, for comparison the dashed line shows the WFD prescribed concentration value for individual pesticides of $0.1 \mu \mathrm{g} / \mathrm{L}$. The high proportion of results below the detection limit are reflected in the box plots, which only show inter-quartile ranges for a handful of compounds. As discussed above, most plots show the highest outliers in the distributions for sites in England. However, for $\Sigma$ pesticides (Fig. 2a), atrazine, DEA and Lindustrials (Fig. 2b) the median values are greater in the sites from France. Results from a Wilcoxon rank sum test are shown at the top of Fig. 2 and Fig. S1, this indicates that population mean ranks do not differ significantly at the $\mathrm{p}=0.05$ level for all compounds except atrazine, caffeine, carbamazepine and $\Sigma$ PPCPLs.

Stuart et al. (2012) evaluated a wider national data set from the Environment Agency using the same analytical method. This study also found atrazine to be the most widely detected compound, but also found phenanthrene and fluoranthene to be widely detected as well as 
desethyl atrazine, caffeine and simazine. Carbamazepine was found to be the second most frequently detected pharmaceutical in almost all samples where any pharmaceuticals were detected and ibuprofen in almost $40 \%$ of such samples from the Rhône-Alpes area of France (Vulliet and Cren-Olivé 2011).

In a pan-European study, Loos et al. (2010) found DEET, caffeine and perflurooctanoic acid to be the most widely detected polar organics with atrazine the fourth most frequently detected, DEA the fifth, simazine the tenth and carbamazepine the eleventh most widely detected compound, our results broadly confirm these findings. Sorensen et al. (2014) found that DEET was the most commonly detected MO in both shallow wells and at depth in the karstic Kabwe Dolomite aquifer in Zambia. Barnes et al. (2008) do not give a detailed breakdown of detection frequency for individual compounds, but for USA groundwater for non-pesticides they report that DEET, bisphenol A, tri(chloroethyl)phosphate (flame retardant), sulfamethoxazole (antibiotic) and 4-octylphenol monoethoxylate (surfactant breakdown product) were the five most frequently detected compounds. Overall plasticisers, insect repellent, flame retardants, antibiotics and solvents were the most frequently detected groups of compounds.

\subsection{Spatial distribution of selected compounds}

At this scale carbamazepine (Fig. 3a) shows a cluster of high detections in England in the greater London area and a few detections on the south coast. There are isolated detections in the concealed part of the Chalk, however the vast majority are located on the edge of the Palaeogene cover. In France there are higher detections located across the Chalk aquifer, south of Lille, near Reims and to the west and south of Rouen. The coincidence of the high detections on the edge of the Palaeogene could be explained in terms of the development of karstic features associated with the Palaeogene margin (MacDonald et al., 1998), and risk of rapid subsurface transport of contaminants to depth with reduced dilution and attenuation. 
There is no significant relationship between the occurrence of MOs and the karstic nature in the French sites although it is difficult to generalise as there are relatively few detections and smaller numbers of samples.

For caffeine at the scale shown (Fig. 3b) there is an isolated region of higher detections in the vicinity of Amiens, in England the detections are again focused around North London in the Stevenage area, and again there are several detects close to the edge of the Palaeogene.

The spatial pattern of $\Sigma$ PPCPL was very similar to and governed by the distribution of caffeine.

For bisphenol-A (Fig. 4a) there is a cluster of three detections in southern England, one close to Salisbury and two to the east of Salisbury. In France there is a cluster of four detections between Amiens and Lille. DEHP detections are noticeably higher and more widespread in France compared to England (Fig. 4b), with the largest proportion of high detections found in northern France in an arc between Lille and Le Havre. In England there are a few isolated detections of high concentrations in the northern part of the London Basin, in Kent and East Anglia (E England). Chlorodibromomethane and Eindustrial compounds show a cluster of high detections in Hampshire and along the South Downs (Figs. 4c and 4d), in France the highest detects are located in a belt north of Paris close to Amiens, Lille and south west of Rouen.

In England, atrazine (Fig. 5a) and DEA have a very similar distribution across exposed Chalk in Hampshire (S England), Dorset (SW England), north of London and East Anglia (E England). The largest cluster of high $\Sigma$ pesticide detections in England (not shown here) were also found located on the east coast in rural East Anglia. In France high atrazine detects are widespread across the Chalk outcrop. In contrast to pesticide detections, $\Sigma$ PPCPL distributions are shown in Fig. 5b. These show a cluster of high detections $(>0.1 \mu \mathrm{g} / \mathrm{L})$ in 
both the concealed and exposed North London Chalk, with isolated high detections south of London and in East Anglia. In France high detections are clustered close to Amiens. For oxadixyl there are relatively few detections in central East Anglia and in the south near to Felixstowe and a high values are found in the Champagne area which known for its wine production. Oxadixyl was mainly used for fungus control on soft fruit in England and also on vines in France.

\subsection{Relationships with selected covariates: aquifer concealment, land use and well and water level depth}

\section{Aquifer concealment}

Total pesticides (Fig. 6) as well as atrazine, its BDPs (Fig. S2) are generally higher in boreholes where the Chalk is exposed. There are higher median values for Sindustrials $(\mathrm{p}=0.76)$ and $\Sigma$ PPCPL $(\mathrm{p}=0.07)$ in exposed Chalk sites. This result seem logical as the route for most of these compounds to reach the subsurface would be ground application or runoff from hard standing, whether in the agricultural or urban setting.

In contrast, median caffeine $(\mathrm{p}=0.009)$ and carbamazepine $(\mathrm{p}=0.07)$ concentrations are significantly higher in the concealed sites (Fig. S2), where more suboxic groundwater conditions are likely. Fram and Belitz (2011) comment on the environmental persistence of carbamazepine due to low degradation and lack of sorption in water sediment system, to the lack of hydrolysis and to its existence as a neutral molecule at environmental $\mathrm{pHs}$ and consequent lack of reaction with negatively charged surfaces in aquifer sediments. Togola et al. (2014) determined sorption constant for 3 soils and 2 sediments. The sorption constants were found to be rather high, and therefore a retardation factor is implied. Miao et al. (2005) showed that carbamazepine was relatively persistent during wastewater treatment and Drewes et al. (2003) demonstrated its persistence during recharge with treated wastewater. Miao et al. 
(2005) assess caffeine as being readily biodegradable during wastewater treatment. Drewes et al. (2003) demonstrated removal of caffeine by groundwater recharge with treated wastewater. (Hillebrand et al. 2012) use caffeine as an indicator of untreated wastewater in karst systems.

For bisphenol A there are many more detections in the exposed sites but there are no statistically significant differences in median values compared to concealed sites (Fig. S2). Cousins et al. (2002) observed aerobic degradation to be the dominant loss process with anaerobic rates being slower (Halling-Sørensen et al. 1998).

\section{Land use, borehole depth and water levels}

MO detections in groundwater are not very clearly related to land use class (Fig. 7). In terms of number of detections both $\Sigma$ PPCPLs and Eindustrial compounds are highest in natural areas. This conclusion may not be entirely surprising since in this study we assess land use using a radial search around the well head vicinity whereas borehole catchments for abstractions in the Chalk tend to be very directional and may extend for several kilometres, especially in karstic areas. However, some individual pesticides, such as oxadixyl and bentazone, do appear to be associated with arable areas (Fig. S3). Overall, the land use classifications used in this study are a very crude measure of likely MOP loading to the subsurface. Indeed, as pesticides are usually specific to a crop, a sole discrimination between urban/agricultural/pasture may not be adequate. In addition some compounds registered as pesticides and are also used as biocides (e.g. diuron).

Atrazine historically had both agricultural and amenity area applications and atrazine, its BDPs and its replacement diuron (in England) are quite widely found, which perhaps reflects why the high frequency of detections are in urban sites. In France, agricultural uses of diuron were banned in 2008 after a reduction in the allowable rate of application in 2003. Most other 
compounds are also found across all land use types (see Fig. S3). This must be related to the wide number and distribution of sources of these compounds in the environment i.e. from wastewater impacted surface water, septic tanks and sewage sludge spreading.

In general the arable agricultural boreholes sampled in this study are deeper than boreholes in other land use types (Fig. 8). This has the effect that industrial compounds, $\Sigma$ pesticides, and $\Sigma$ PPCPLs that are detected down to $100 \mathrm{~m}$ in arable areas, all be it at low concentrations. For individual compounds these are shown in Fig. S4, caffeine can be high in shallow urban and arable groundwater, chlorodibromomethane was detected at highest concentrations in shallow sites from a range of land use types, highest concentrations of atrazine in BDPs were detected in shallow arable sites.

Fig. 9 shows cross plots for total concentrations for pesticides, industrials and PPCPLs in relation to depth to water at the borehole and land use. This shows a similar picture to borehole depth with an overall decrease in detections and concentrations with depth and detections $>50 \mathrm{mbgl}$ largely restricted to arable sites. For both $\Sigma$ pesticides and $\Sigma$ industrials shallow sites show a significant number of sites with concentrations $>0.1 \mu \mathrm{g} / \mathrm{L}$.

\subsection{Controls and mechanisms}

Concentrations of MOs in groundwater are controlled both by the route and pattern of ingress to the subsurface and by persistence in groundwater. In this study land use and Chalk aquifer concealment have been used to address the potential spatial distribution of MO sources and migration to groundwater. Fate and transport in the Chalk is related both to mobility and persistence. Mobility can be described by solubility and by $\mathrm{K}_{\mathrm{ow}}$ (Table 1). In general most organic compounds are more readily degraded under aerobic conditions but there are a number of well-established exceptions including some halogenated compounds (Hill and 
McCarty 1967, Mihelcic and Luthy 1988). Metabolites and BDPs frequently are more polar and water soluble than their parent compounds and are therefore more mobile.

The "life-style" compounds caffeine and cotinine (nicotine BDP) and metronidazole are the most soluble compounds detected in this study by some margin and also have low $\mathrm{K}_{\mathrm{ow}}$. Other mobile compounds in Table 1 include oxadixyl, BAM, DEA, methyl paraben, and the plasticisers DEP, dimethylphthalate and BBSA. Overall BDPs are significantly represented in this group. DEA, bentazone, BAM and caffeine have the highest mammalian toxicities.

Persistence remains challenging to assess with reported half lives in groundwater being very scarce and variable. For some compounds their continued detection in groundwater is indicative of persistence in soil, unsaturated or saturated zones. For example, atrazine, simazine and oxadixyl have all been withdrawn from use in the EU for some years yet continue to be routinely detected in groundwater. For atrazine there is long-established evidence that it may be very persistent under conditions of limited oxygen (Papiernik and Spalding 1998, Schwab et al. 2006) and in the unsaturated zone below the soil zone where remobilisation is possible (Kruger et al. 1993, Jablonowski et al. 2009). For oxadixyl the soil half-life is currently commonly given as 60 to 90 days (Wightwick et al. 2010). An older reference states that oxadixyl is slowly degraded in soil with a half-life of about 16 months (USEPA 1992). The complexity of interpreting MO ingress and occurrence in groundwater is illustrated using a specific example from this study.

\section{Caffeine and Carbamazepine in the London Basin}

Groundwater in the Chalk of the London and Paris Basins is confined by the overlying Palaeogene deposits. Most groundwater was recharged during the Holocene and geochemical conditions are very similar in both basins with "fossil" groundwater being encountered in the confined part of the aquifer (Edmunds et al. 1987; Kloppmann et al. 1998). The presence of MOs suggests a rapid pathway and component of modern recharge in the Chalk. In north 
London, estimates of groundwater age using tritium and carbon isotopes range from 49008000 years along the upper confined section of the River Lee, while groundwater in the southern section of the river is influenced by modern water from the river through "windows" in the Palaeogene London Clay (Downing et al. 1979). Following a number of trials, from 1995 onwards the Lee Valley area as well as Enfield/Haringey has been used for the North London Artificial Aquifer Recharge Scheme with recharge rates of up to 40 ML/day of mains water to the Chalk and the overlying Thanet Formation (UK Groundwater Forum 2013; O'Shea and Sage 1999, Flavin and Joseph 1983).

Therefore a number of potential mechanisms for caffeine and other MO contaminants to get into the confined chalk aquifer in north London could be postulated:

- Rapid pathways through the overlying London Clay and Lambeth Group possibly through windows in the Palaeogene.

- Long-term artificial recharge using treated/or partially treated water containing organic compounds

- Unrecorded faulting in the Chalk providing rapid pathways in the saturated zone (Royse et al. 2012)

The present study does not include samples from the confined Paris Basin Chalk but we could speculate that there may be similar possibilities for detection of modern MOs in vulnerable locations based on observations from the London Basin.

\section{Conclusions}

- A range of MOs, including emerging compounds, were detected in the Chalk aquifers of England and France. In England the highest concentrations detected were for the plasticisers bisphenol A (up to $100 \mu \mathrm{g} / \mathrm{L}$ ), DEP, and BBSA, the pesticides 
diphenylamine, atrazine and its breakdown product DEA, caffeine and anthracene. In France, frequencies of detection were higher but the maximum concentrations of MOs detected were much lower than England, with the highest result being for bisphenol A (up to $1.4100 \mu \mathrm{g} / \mathrm{L}$ ), BBSA and DEHP, and with 20 of the 32 study compounds not detected at all including anthracene, DEET, several parabens and ibuprofen. More work is needed to evaluate MO occurrence, and likely risks for groundwater dependant receptors, as part of the ongoing assessments to inform policy on the priority substances as well as the EU watch list mechanism. Broad screening analytical methods are a particularly important tool as part of the process to gather evidence to inform policy on new emerging contaminants.

- Aquifer concealment was found to be important factor for some compounds. BBSA and a range of pesticides including atrazine, its BDPs and $\Sigma$ pesticides are generally higher in boreholes where the Chalk is exposed whereas caffeine and bisphenol A were generally higher in the concealed aquifer.

- Evidence for rapid pathways for contaminant migration associated with vulnerable hydrogeological setting. For example, for caffeine the main cluster of high values is in the northern part of the London Basin where the Chalk is concealed. The possible reasons for this are discussed and include groundwater surface water interaction, artificial recharge and karstic features in the chalk associated with the Paleogene margin. For carbamazepine occurrence in English Chalk was also clustered in the London basin close to the margin of the Paleogene cover as well as a few detections in the southern portion of the Chalk aquifer. In France detections were more wide spread and again perhaps associated with karstic settings including karstic development close to the margin of Paleogene cover. 
- MO concentrations have some relationship to land use. However, the multiplicity of sources, such as application of sewage sludge to land, rapid migration pathways such as karstic features and the use of pesticides on different land use types mean that they are generally widespread and a range of MOs are found, including pesticides still allowed or withdrawn, their BDPs, THMs and some emerging contaminants.

\section{Acknowledgments}

The authors are grateful to Alwyn Hart and Wayne Civil of the Environment Agency for England for access to monitoring data and providing details on the analysis undertaken by the UK National Laboratory Service. They also thank the French Ministry of Ecology, sustainable development and Energy (MEDDE), the national Office for Water and aquatic environments (ONEMA) and the basin agencies that participated in the financing and technical realisazation of the national screening. Comments from an internal BGS reviewer, Daren Gooddy, are acknowledged. This paper is published with the permission of the Executive Director of the British Geological Survey.

\section{References}

Amalric L., Baran N., Coureau C., Maingot L., Buron F., Routier S. 2013. Analytical developments for 47 pesticides: first identification of neutral chloroacetanilide derivatives in French groundwater. International Journal of Environmental Analytical Chemistry 93: 1660-1675

Baran, N., Lepiller, M., Mouvet, C. (2008) Agricultural diffuse pollution in a chalk aquifer (Trois Fontaines, France): Influence of pesticide properties and hydrodynamic constraints. Journal of Hydrology 358(1-2), 56-69.

Barnes, K.K., Kolpin, D.W., Furlong, E.T., Zaugg, S.D., Meyer, M.T., Barber, L.B. (2008) A national reconnaissance of pharmaceuticals and other organic wastewater contaminants in the United States: I) Groundwater. Science of the Total Environment 402(2-3), 192200.

Baxter, K.M. (1985a) The effects on groundwater quality of the introduction of secondary sewage treatment to an effluent recharge site on the Chalk of southern England. Journal of Hydrology 77, 333-359.

Baxter, K.M. (1985b) The effects of a hazardous and a domestic waste landfill on the trace organic quality of chalk groundwater at a site in East Anglia. Science of the Total Environment 47, 93-98.

Chilton, P.J., Stuart, M.E., Gooddy, D.C., Williams, R.J., Johnson, A.C. (2005) Pesticide fate and behaviour in the UK Chalk aquifer, and implications for groundwater quality Quarterly Journal of Engineering Geology and Hydrogeology 38, 65-81.

Cousins, I.T., Staples, C.A., Klecka, G.M., Mackay, D. (2002) A multimedia assessment of the environmental fate of bisphenol A. Human Ecol. Risk Assess. 8(5), 1107-1135.

Crampon, N., Mania, J., Caous, J.Y. (2000) Aquifères et ressources en eau souterraine du Nord-Pas-de-Calais. Annales de la Societé Géologique du Nord 10, 219-232. 
Downing, R.A., Pearson, F.J., Smith, D.B. (1979) The flow mechanisms in the Chalk based on radio-isotope analysis in the London basin. Journal of Hydrology 40, 67-83.

Drewes, J.E., Heberer, T., Rauch, T., Reddersen, K. (2003) Fate of pharmaceuticals during ground water recharge. Ground Water Monit R 23, 64-72.

EC (1992) The Habitats Directive 92/43/EEC, European Commission.

Edmunds, W.M., Shand, P. (eds) (2008) Natural Groundwater Quality, Blackwell, Oxford.

Edmunds, W.M., Cook, J.M., Kinniburgh, D.G., Miles, D.L., Trafford, J.M. (1989) Trace element occurrence in British groundwaters, British Geological Survey.

Edmunds, W. M., Cook J. M., Darling W. G., Kinniburgh D. G., Miles D. L., Bath A. H., Morgan-Jones M., Andrews J. N. (1987). Baseline geochemical conditions in the Chalk aquifer, Berkshire, UK: a basis for groundwater quality management. Applied Geochemistry, 2(3), 251-274.

EEA (2006) Corine Land Cover 2006 raster data, European Environment Agency.

Flavin, R. J., Joseph, J. B. (1983). The hydrogeology of the Lee Valley and some effects of artificial recharge. Quarterly Journal of Engineering Geology and Hydrogeology, 16(1), 65-82.

Focazio, M.J., Kolpin, D.W., Barnes, K.K., Furlong, E.T., Meyer, M.T., Zaugg, S.D., Barber, L.B., Thurman, M.E. (2008) A national reconnaissance for pharmaceuticals and other organic wastewater contaminants in the United States: II) Untreated drinking water sources. Science of the Total Environment 402(2-3), 201-216.

Foster, S.S.D., Chilton, P.J., Stuart, M.E. (1991) Mechanisms of groundwater pollution by pesticides. Journal of the Institution of Water and Environmental Management 5, 186193.

Fram, M.S., Belitz, K. (2011) Occurrence and concentrations of pharmaceutical compounds in groundwater used for public drinking-water supply in California. Science of the Total Environment 409(18), 3409-3417.

Gooddy, D.C., Chilton, P.J., Harrison, I. (2002) A field study to assess the degradation and transport of diuron and its metabolites in a calcareous soil. Science of the Total Environment 297(1-3), 67-83.

Gooddy, D.C., Mathias, S.A., Harrison, I., Lapworth, D.J., Kim, A.W. (2007) The significance of colloids in the transport of pesticides through Chalk. Science of the Total Environment 385(1-3), 262-271.

Halling-Sørensen, B., Nors Nielsen, S., Lanzky, P.F., Ingerslev, F., Holten Lützhøft, H.C., Jørgensen, S.E. (1998) Occurrence, fate and effects of pharmaceutical substances in the environment- A review. Chemosphere 36(2), 357-393.

Hill, D.W., McCarty, P.L. (1967) Anaerobic degradation of selected chlorinated hydrocarbon pesticides. Journal (Water Pollution Control Federation), 1259-1277.

Hillebrand, O., Nödler, K., Licha, T., Sauter, M., Geyer, T. (2012) Caffeine as an indicator for the quantification of untreated wastewater in karst systems. Water Research 46(2), 395402.

INSEE (2010) Populations légales 2010 pour les départements et les collectivités d'outre-mer, Institut national de la statistique et des études économiques

Jablonowski, N.D., Koppchen, S., Hofmann, D., Schaffer, A., Burauel, P. (2009) Persistence of 14C-labeled atrazine and its residues in a field lysimeter soil after 22 years. Environ Pollut 157(7), 2126-2131.

Johnson, A.C., Besien, T.J., Bhardwaj, C.L., Dixon, A., Gooddy, D.C., Haria, A.H. and White, C. (2001) Penetration of herbicides to groundwater in an unconfined chalk aquifer following normal soil applications. Journal of Contaminant Hydrology 53, 101-117. 
Johnson, A.C., Hughes, C.D., Williams, R.J., Chilton, P.J. (1998) Potential for aerobic isoproturon biodegradation and sorption in the unsaturated and saturated zones of a chalk aquifer. Journal of Contaminant Hydrology 30, 281-297.

Katz, B.G., Griffin, D.W., Davis, J.H. (2009) Groundwater quality impacts from the land application of treated municipal wastewater in a large karstic spring basin: Chemical and microbiological indicators. Science of the Total Environment 407(8), 2872-2886.

Kloppmann, W., Dever, L., Edmunds, W.M. (1998) Residence time of Chalk groundwaters in the Paris Basin and the North German Basin: a geochemical approach. Applied Geochemistry 13(5), 593-606.

Kolpin, D.W., Furlong, E.T., Meyer, M.T., Thurman, E.M., Zaugg, S.D., Barber, L.B., Buxton, H.T. (2002) Pharmaceuticals, hormones, and other organic wastewater contaminants in US streams, 1999-2000: a national reconnaissance. Environmental Science \& Technology 36, 1202-1211.

Kruger, E.L., Somasundaram, L., Coats, J.R., Kanwar, R.S. (1993) Persistence and degradation of [14C] atrazine and [14C]deisopropylatrazine as affected by soil depth and moisture conditions. Environmental Toxicology and Chemistry 12(11), 1959-1967.

Kümmerer, K. (2009) The presence of pharmaceuticals in the environment due to human use present knowledge and future challenges. Journal of Environmental Management 90(8), 2354-2366.

Lapworth, D.J., Gooddy, D.C. (2006) Source and persistence of pesticides in a semi-confined chalk aquifer of southeast England. Environmental Pollution 144(3), 1031-1044.

Lapworth, D.J., Baran, N., Stuart, M.E., Ward, R.S. (2012) Emerging organic contaminants in groundwater: A review of sources, fate and occurrence. Environmental Pollution 163, 287-303.

Lloyd, J.W., Hiscock, K. (1990) Chalk, Thomas Telford, London.

Loos, R., Locoro, G., Comero, S., Contini, S., Schwesig, D., Werres, F., Balsaa, P., Gans, O., Weiss, S., Blaha, L., Bolchi, M., Gawlik, B.M. (2010) Pan-European survey on the occurrence of selected polar organic persistent pollutants in ground water. Water Research 44(14), 4115-4126.

Miao, X.-S., Yang, J.-J., Metcalfe, C.D. (2005) Carbamazepine and Its metabolites in wastewater and in biosolids in a municipal wastewater treatment plant. Environ. Sci. Technol. 39(19), 7469-7475.

Mihelcic, J.R., Luthy, R.G. (1988) Degradation of polycyclic aromatic hydrocarbon compounds under various redox conditions in soil-water systems. Applied and Environmental Microbiology 54(5), 1182-1187.

Morasch, B. (2013) Occurrence and dynamics of micropollutants in a karst aquifer. Environmental Pollution 173(0), 133-137.

O'Shea, M.J., Sage, R. (1999) Aquifer recharge: An operational drought-management strategy in North London. Water and Environment Journal 13(6), 400-405.

Papiernik, S.K., Spalding, R.F. (1998) Atrazine, deethylatrazine, and deisopropylatrazine persistence measured in groundwater in situ under low-oxygen conditions. Journal of Agricultural and Food Chemistry 46(2), 749-754.

Royse, K.R., de Freitas, M., Burgess, W.G., Cosgrove, J., Ghail, R.C., Gibbard, P., King, C., Lawrence, U., Mortimore, R.N., Owen, H., Skipper, J. (2012) Geology of London, UK. Proceedings of the Geologists' Association 123(1), 22-45.

Schwab, A.P., Splichal, P.A., Banks, M.K. (2006) Persistence of atrazine and alachlor in ground water aquifers and soil. Water, Air, \& Soil Pollution 171(1-4), 203-235.

Sorensen, J. P. R., Lapworth, D. J., Nkhuwa, D. C. W., Stuart, M. E., Gooddy, D. C., Bell, R. A., Chirwa, M., Kabika, J., Liemisa, M., Chibesa, M., Pedley, S. (2014). Emerging 
contaminants in urban groundwater sources in Africa. Water Research, in press. http://dx.doi.org/10.1016/j.watres.2014.08.002.

Stuart, M.E., Lapworth, D.J., Crane, E.J., Hart, A. (2012) Review of risk from potential emerging contaminants in UK groundwater. Science of the Total Environment 416, 121.

Stuart, M. E., Lapworth, D. J., Thomas, J., Edwards, L. (2014). Fingerprinting groundwater pollution in catchments with contrasting contaminant sources using microorganic compounds. Science of the Total Environment, 468, 564-577.

Stuart, M.E., Manamsa, K., Talbot, J.C., Crane, E.J. (2011) Emerging contaminants in groundwater British Geological Survey.

Swartz, C.H., Reddy, S., Benotti, M.J., Yin, H., Barber, L.B., Brownawell, B.J., Rudel, R.A. (2006) Steroid estrogens, nonylphenol ethoxylate metabolites, and other wastewater contaminants in groundwater affected by a residential septic system on Cape Cod, MA. Environmental Science \& Technology 40(16), 4894-4902.

Togola, A., Baran, N., Coureau, C. (2014). Advantages of online SPE coupled with UPLC/MS/MS for determining the fate of pesticides and pharmaceutical compounds. Analytical and bioanalytical chemistry, 406(4), 1181-1191.

UK Groundwater Forum (2014). Last accessed on 5 November 2014. http://www.groundwateruk.org/Rising_Groundwater_in_Central_London.aspx

UKWIR (2004) Implications of changing groundwater quality for water resources and the UK water industry: Financial and water resources impacts, UK Water Industry Research.

USEPA (1992) Pesticide Fact Sheet Number 237: Oxadixyl, US Environmental Protection Agency, Washington, DC.

Vulliet, E., Cren-Olivé, C. (2011) Screening of pharmaceuticals and hormones at the regional scale, in surface and groundwaters intended to human consumption. Environmental Pollution 159(10), 2929-2934.

Wightwick, A., Walters, R., Allinson, G., Reichman, S., Menzies, N. (2010) Fungicides. Carisse, O. (ed), pp. 274-304, Intech. 


\section{Fig. captions}

Fig. 1. Map of Southern England and northern France showing Chalk outcrop, Palaeogene cover and sample sites used in the study. Filled symbols are sites that are on exposed Chalk outcrop, unfilled symbols are sites that are either confined or covered with $>10 \mathrm{~m}$ of impermeable superficial cover. Selected major cities are show with square symbols.

Fig. 2 Boxplots comparing detected concentrations of groups of microorganics in the

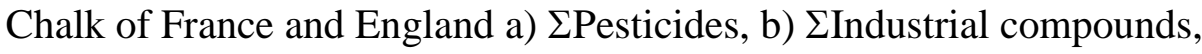
c) $\Sigma$ PPCPL

Fig. 3 Spatial distributions of concentrations of a) carbamazepine ( $\mu \mathrm{g} / \mathrm{L}), \mathrm{b})$ caffeine $(\mu \mathrm{g} / \mathrm{L})$

Fig. 4 Spatial distributions of concentrations of a) Bisphenol A ( $\mu \mathrm{g} / \mathrm{L})$, b) DEHP $(\mu \mathrm{g} / \mathrm{L}), \mathrm{c})$ chlorodibromomethane $(\mu \mathrm{g} / \mathrm{L}), \mathrm{d}) \Sigma$ Industrial compounds $(\mu \mathrm{g} / \mathrm{L})$

Fig. 5 Spatial distributions of concentrations of a) atrazine ( $\mu \mathrm{g} / \mathrm{L})$ and b) $\Sigma$ PPCPL $(\mu \mathrm{g} / \mathrm{L})$

Fig. 6 Comparison of microorganic groups in exposed and concealed chalk a) $\Sigma$ Pesticides $(\mu \mathrm{g} / \mathrm{L})$, b) $\Sigma$ Industrial compounds $(\mu \mathrm{g} / \mathrm{L})$, c) $\Sigma$ PPCPL $(\mu \mathrm{g} / \mathrm{L})$

Fig. $7 \quad$ Comparison of microorganic groups in chalk by land use category a) $\Sigma$ Pesticides ( $\mu \mathrm{g} / \mathrm{L})$, b) $\Sigma$ Industrial compounds ( $\mu \mathrm{g} / \mathrm{L})$, c) $\Sigma \mathrm{PPCPL}(\mu \mathrm{g} / \mathrm{L})$

Fig. 8 Comparison of microorganic groups in chalk by well depth a) $\Sigma$ Pesticides ( $\mu \mathrm{g} / \mathrm{L}), \mathrm{b}) \Sigma$ Industrial compounds $(\mu \mathrm{g} / \mathrm{L})$, c) $\Sigma \operatorname{PPCPL}(\mu \mathrm{g} / \mathrm{L})$. Vertical line shows $0.1 \mathrm{mg} / \mathrm{L}$ EU prescribed concentration value for individual pesticides and BDPs

Fig. 9 Comparison of selected microorganics in chalk by water level a) Caffeine ( $\mu \mathrm{g} / \mathrm{L})$, b) Carbamazepine $(\mu \mathrm{g} / \mathrm{L})$. Vertical line shows $0.1 \mathrm{mg} / \mathrm{L}$ EU prescribed concentration value for individual pesticides and BDPs 


\section{Supplementary information:}

Fig. S1 Comparison of selected microorganic compounds $(\mu \mathrm{g} / \mathrm{L})$ in Chalk in France and England

Fig. S2 Comparison of selected microorganic compounds $(\mu \mathrm{g} / \mathrm{L})$ in exposed and concealed chalk sites

Fig. S3 Comparison of selected microorganic compounds $(\mu \mathrm{g} / \mathrm{L})$ in chalk by land use category

Fig. S4 Comparison of selected microorganic compounds $(\mu \mathrm{g} / \mathrm{L})$ in chalk by well depth

Fig. S5 Comparison of selected microorganic compounds $(\mu \mathrm{g} / \mathrm{L})$ in chalk by water level 


\section{Figures}

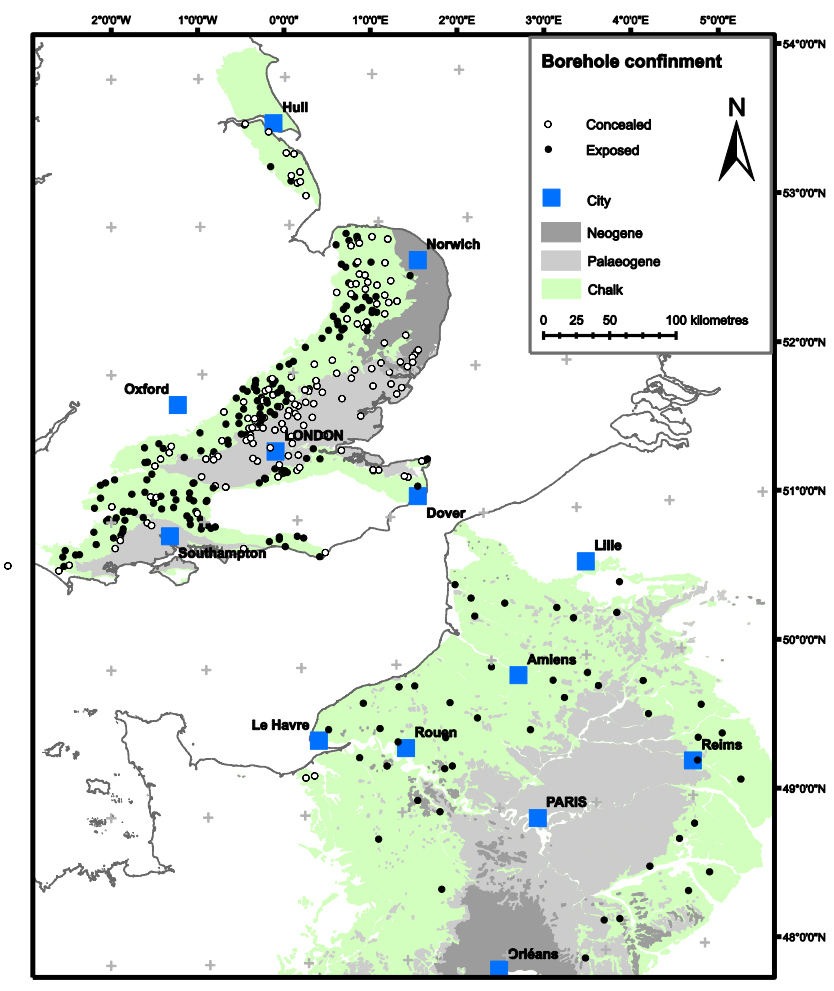

Figure 1. Map of Southern England and northern France showing Chalk outcrop, Palaeogene cover and sample sites used in the study. Filled symbols are sites that are on exposed Chalk outcrop, unfilled symbols are sites that are either confined or covered with $>10 \mathrm{~m}$ of impermeable superficial cover. Selected major cities are show with square symbols.
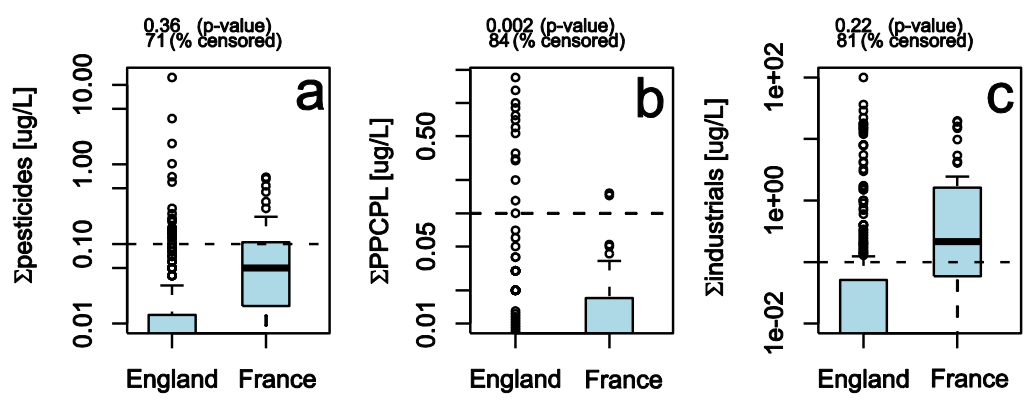

Fig. 2 Boxplots comparing detected concentrations of groups of microorganics in the Chalk of France and England a) $\Sigma$ Pesticides, b) $\Sigma$ Industrial compounds, c) $\Sigma$ PPCPL 

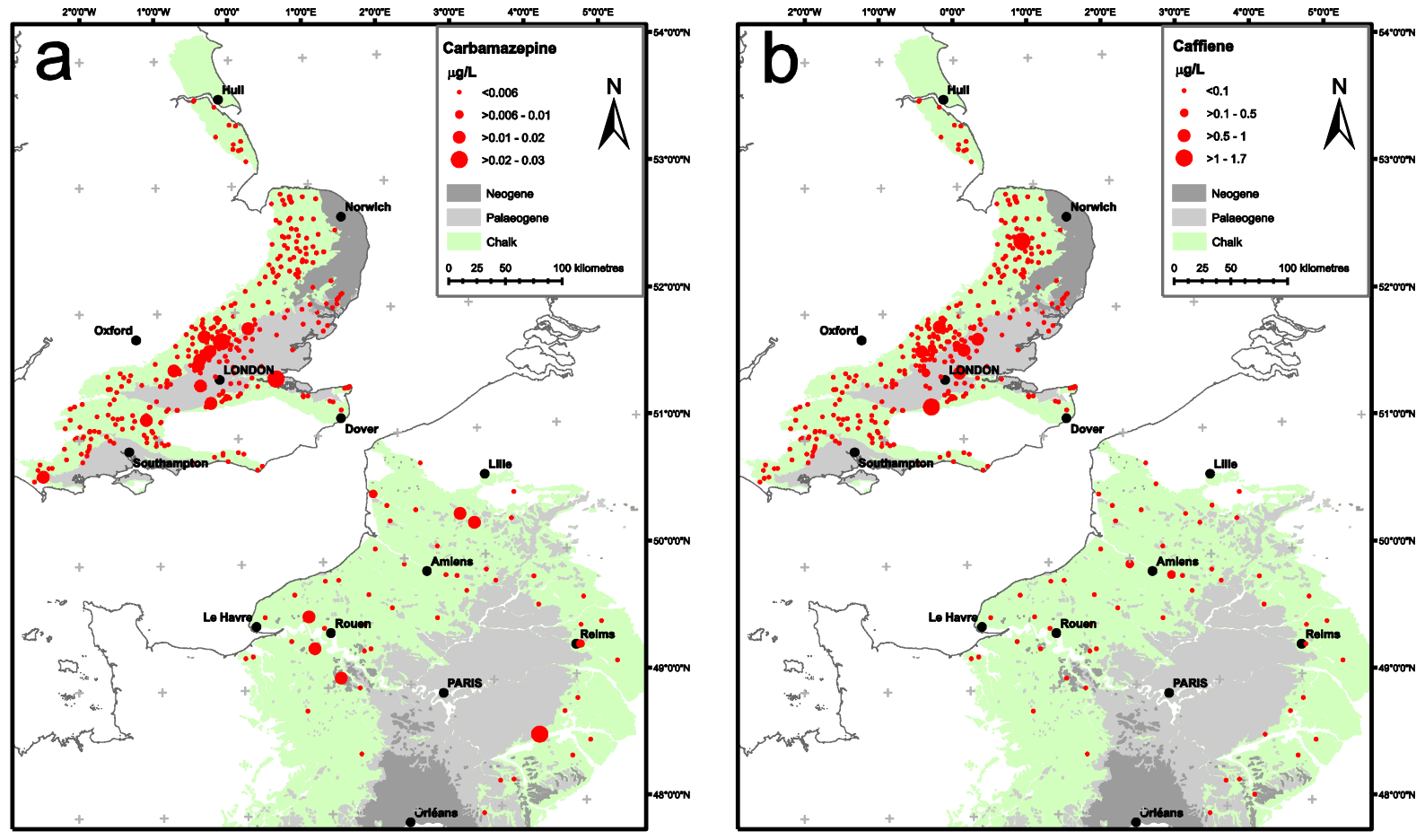

Fig. 3 Spatial distributions of concentrations of a) carbamazepine $(\mu \mathrm{g} / \mathrm{L}), \mathrm{b})$ caffeine $(\mu \mathrm{g} / \mathrm{L})$ 

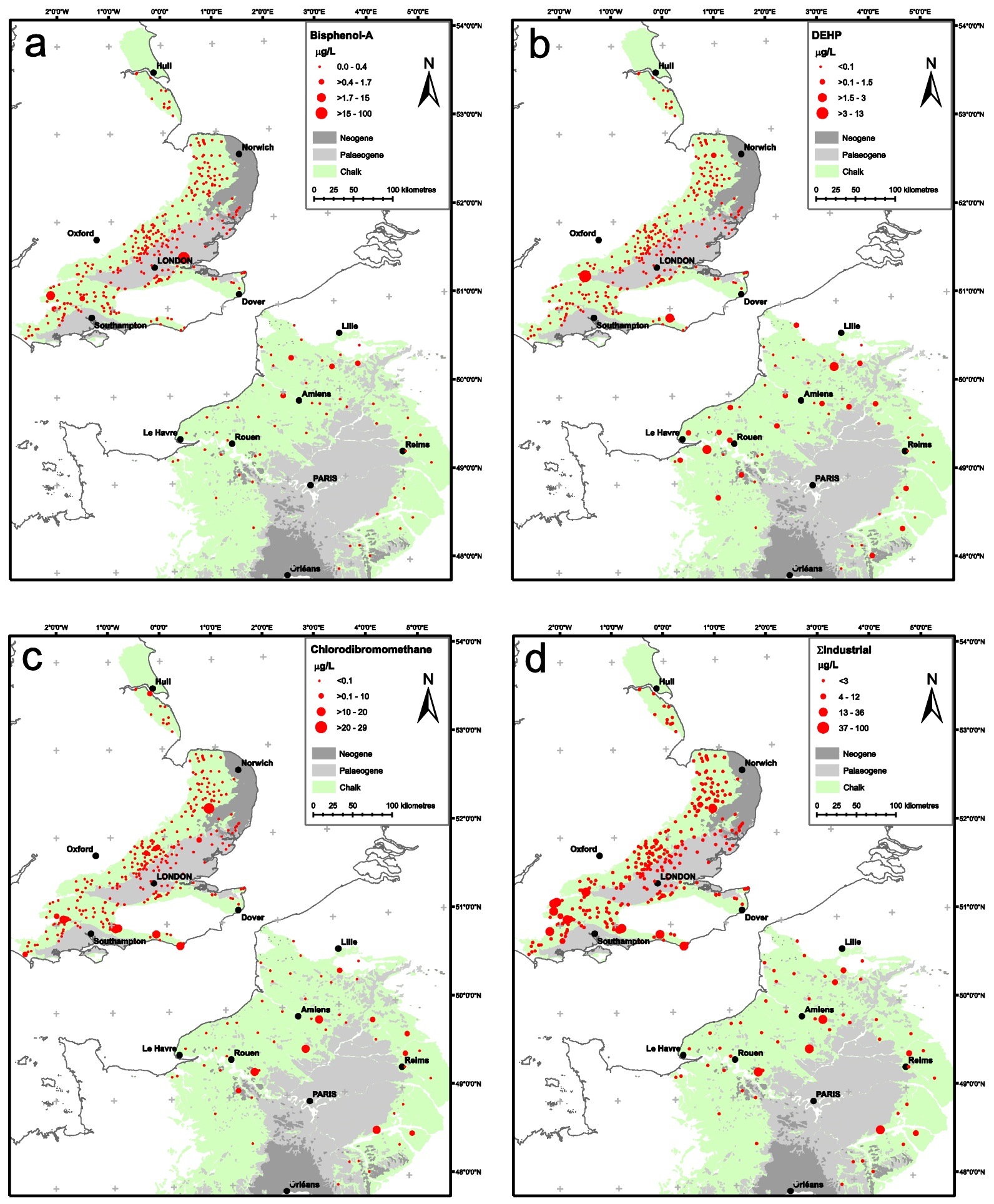

Fig. 4 Spatial distributions of concentrations of a) Bisphenol A ( $\mu \mathrm{g} / \mathrm{L})$, b) DEHP

$(\mu \mathrm{g} / \mathrm{L}), \mathrm{c})$ chlorodibromomethane $(\mu \mathrm{g} / \mathrm{L}), \mathrm{d}) \Sigma$ Industrial compounds $(\mu \mathrm{g} / \mathrm{L})$ 

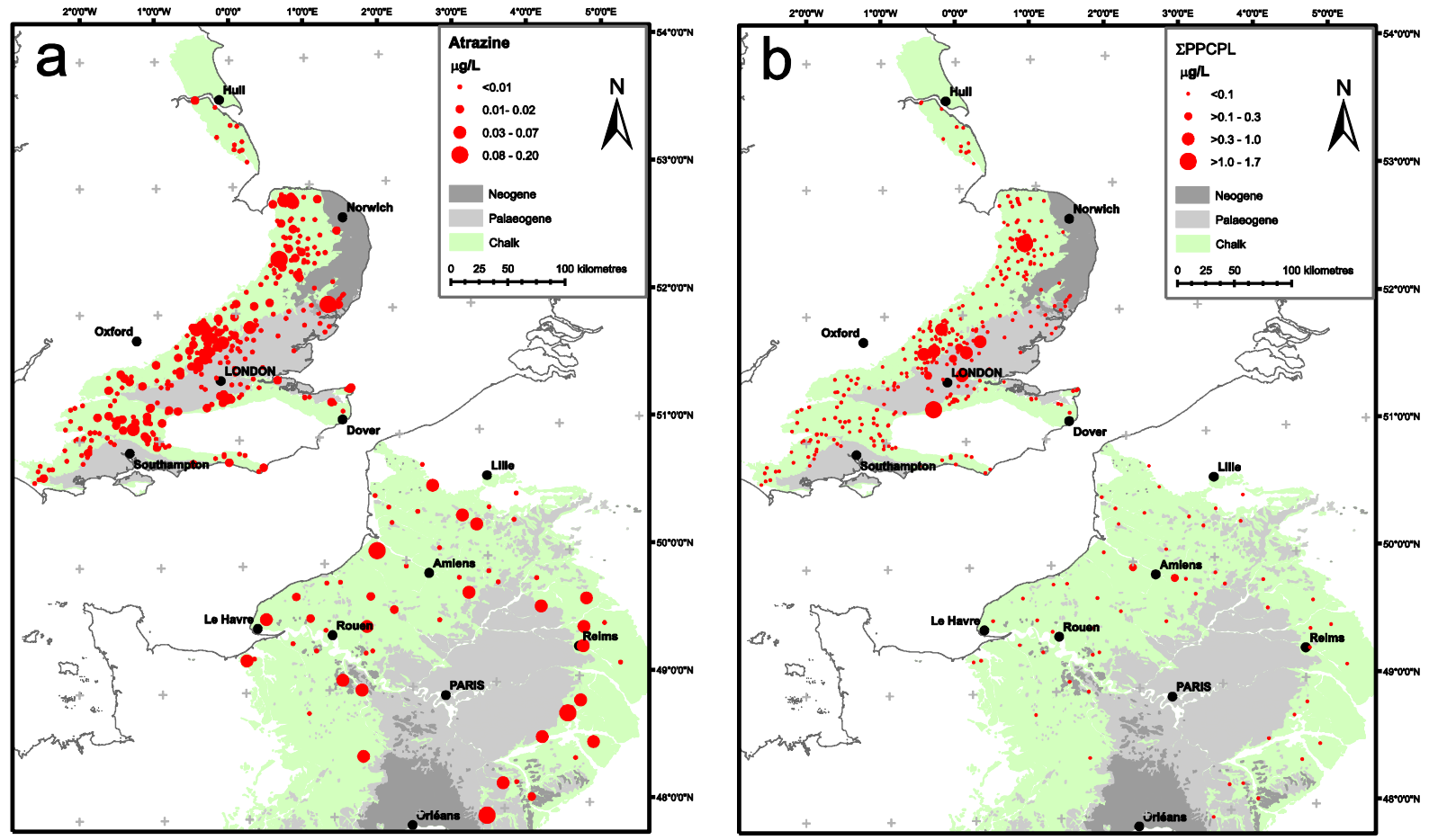

Fig. 5 Spatial distributions of concentrations of a) atrazine ( $\mu \mathrm{g} / \mathrm{L})$ and b) $\Sigma$ PPCPL $(\mu \mathrm{g} / \mathrm{L})$ 

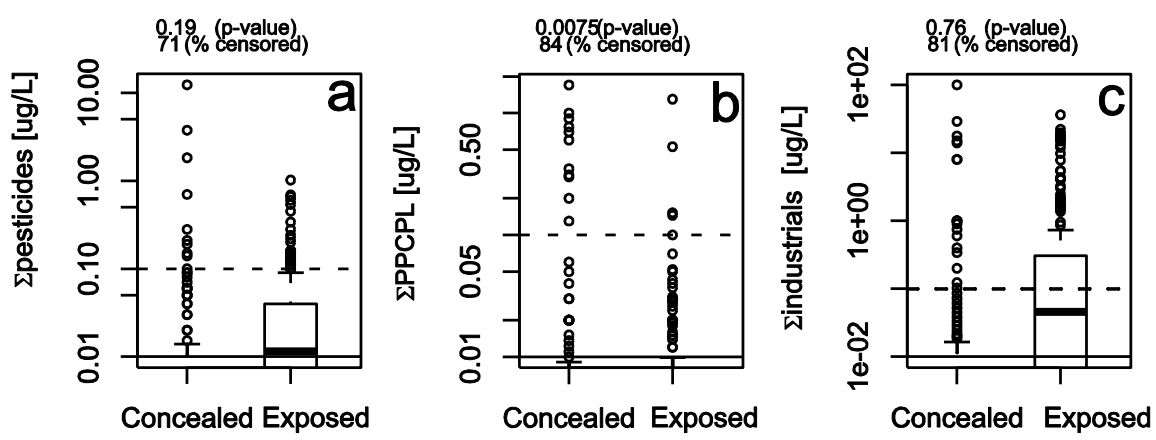

Fig. 6 Comparison of microorganic groups in exposed and concealed chalk

a) $\Sigma$ Pesticides ( $\mu \mathrm{g} / \mathrm{L})$, b) $\Sigma$ Industrial compounds $(\mu \mathrm{g} / \mathrm{L})$, c) $\Sigma$ PPCPL $(\mu \mathrm{g} / \mathrm{L})$
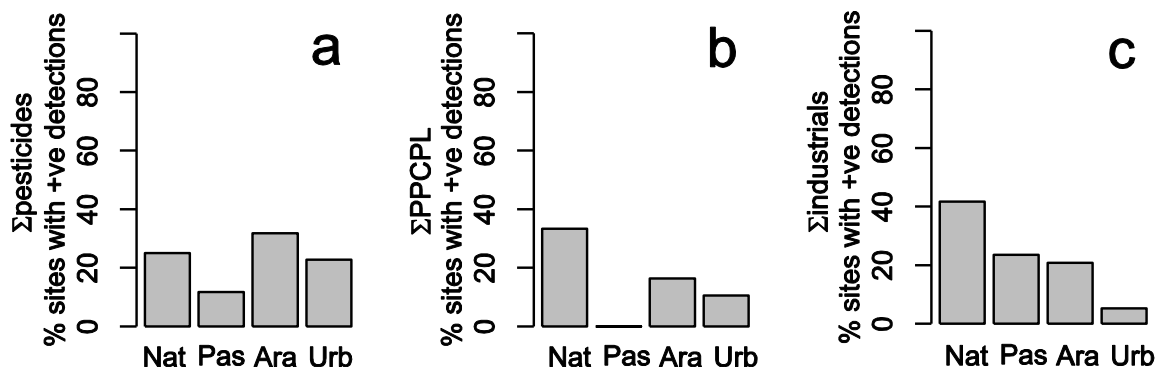

Fig. $7 \quad$ Comparison of microorganic groups in chalk by land use category a) $\Sigma$ Pesticides ( $\mu \mathrm{g} / \mathrm{L})$, b) $\Sigma$ Industrial compounds ( $\mu \mathrm{g} / \mathrm{L})$, c) $\Sigma \mathrm{PPCPL}(\mu \mathrm{g} / \mathrm{L})$
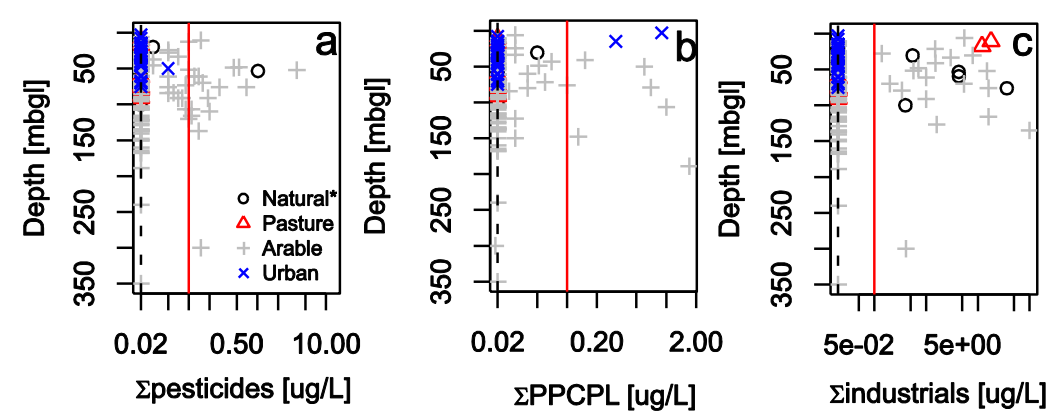

Fig. 8 Comparison of microorganic groups in chalk by well depth a) $\Sigma$ Pesticides ( $\mu \mathrm{g} / \mathrm{L}), \mathrm{b}) \Sigma$ Industrial compounds $(\mu \mathrm{g} / \mathrm{L})$, c) $\Sigma$ PPCPL( $\mu \mathrm{g} / \mathrm{L})$. Vertical line shows $0.1 \mathrm{mg} / \mathrm{L} \mathrm{EU}$ prescribed concentration value for individual pesticides and BDPs 

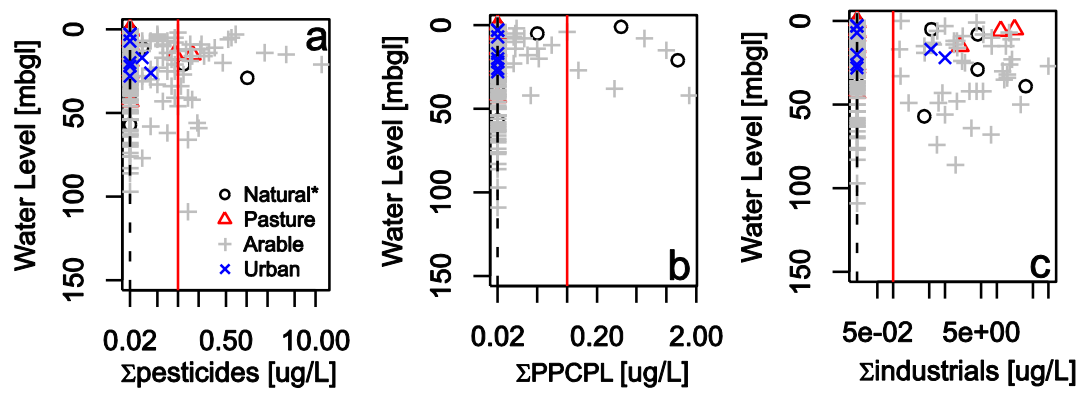

Fig. 9 Comparison of selected microorganics in chalk by water level a) Caffeine $(\mu \mathrm{g} / \mathrm{L})$,

b) Carbamazepine $(\mu \mathrm{g} / \mathrm{L})$. Vertical line shows $0.1 \mathrm{mg} / \mathrm{L} \mathrm{EU}$ prescribed

concentration value for individual pesticides and BDPs

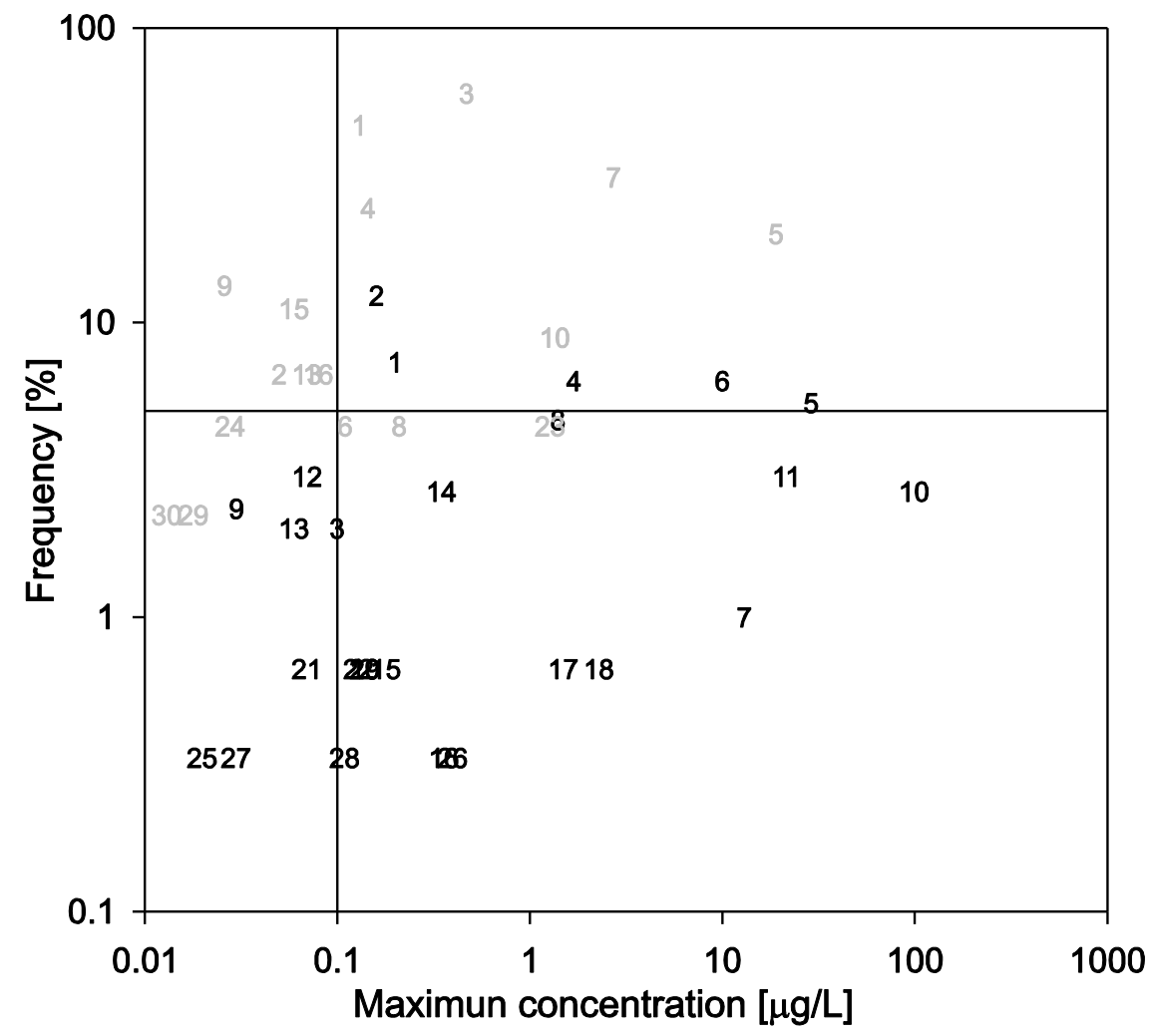

Fig. S1 Cross plot of frequency vs maximum detection $(\mu \mathrm{g} / \mathrm{L})$ for English and French data 

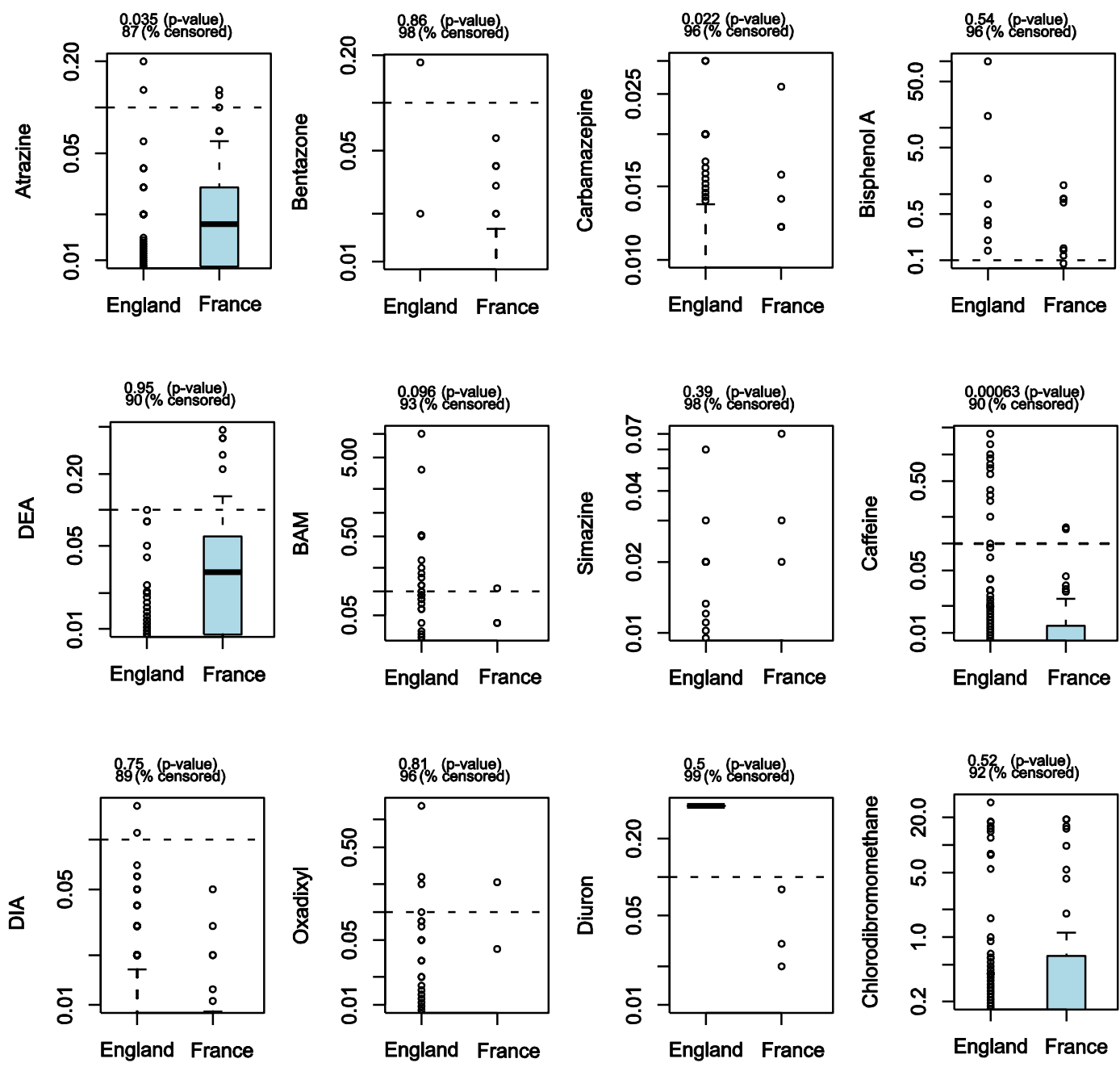

Fig. S2 Comparison of selected microorganic compounds $(\mu \mathrm{g} / \mathrm{L})$ in Chalk in France and England 

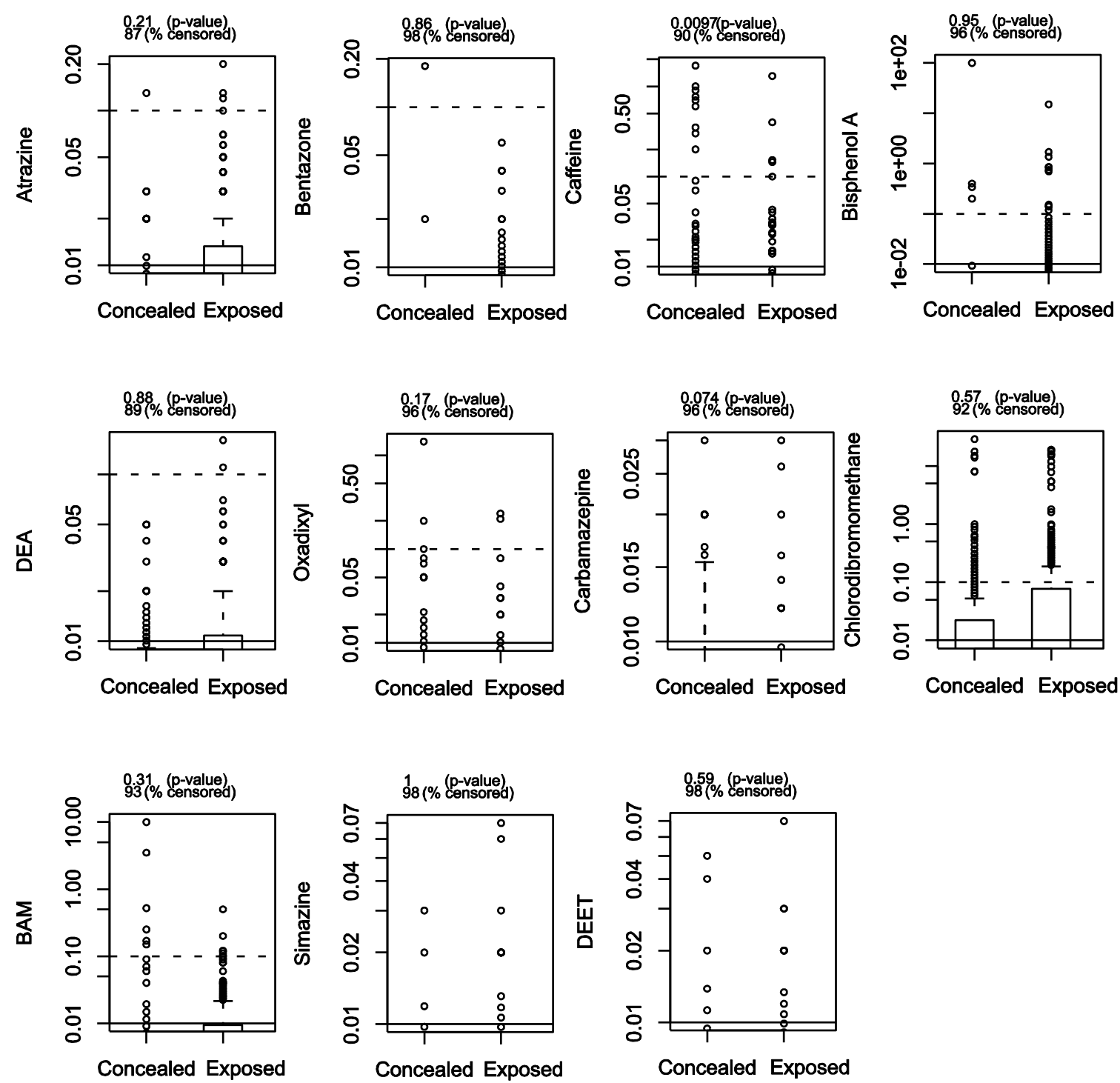

Fig. S3 Comparison of selected microorganic compounds $(\mu \mathrm{g} / \mathrm{L})$ in exposed and concealed chalk sites 

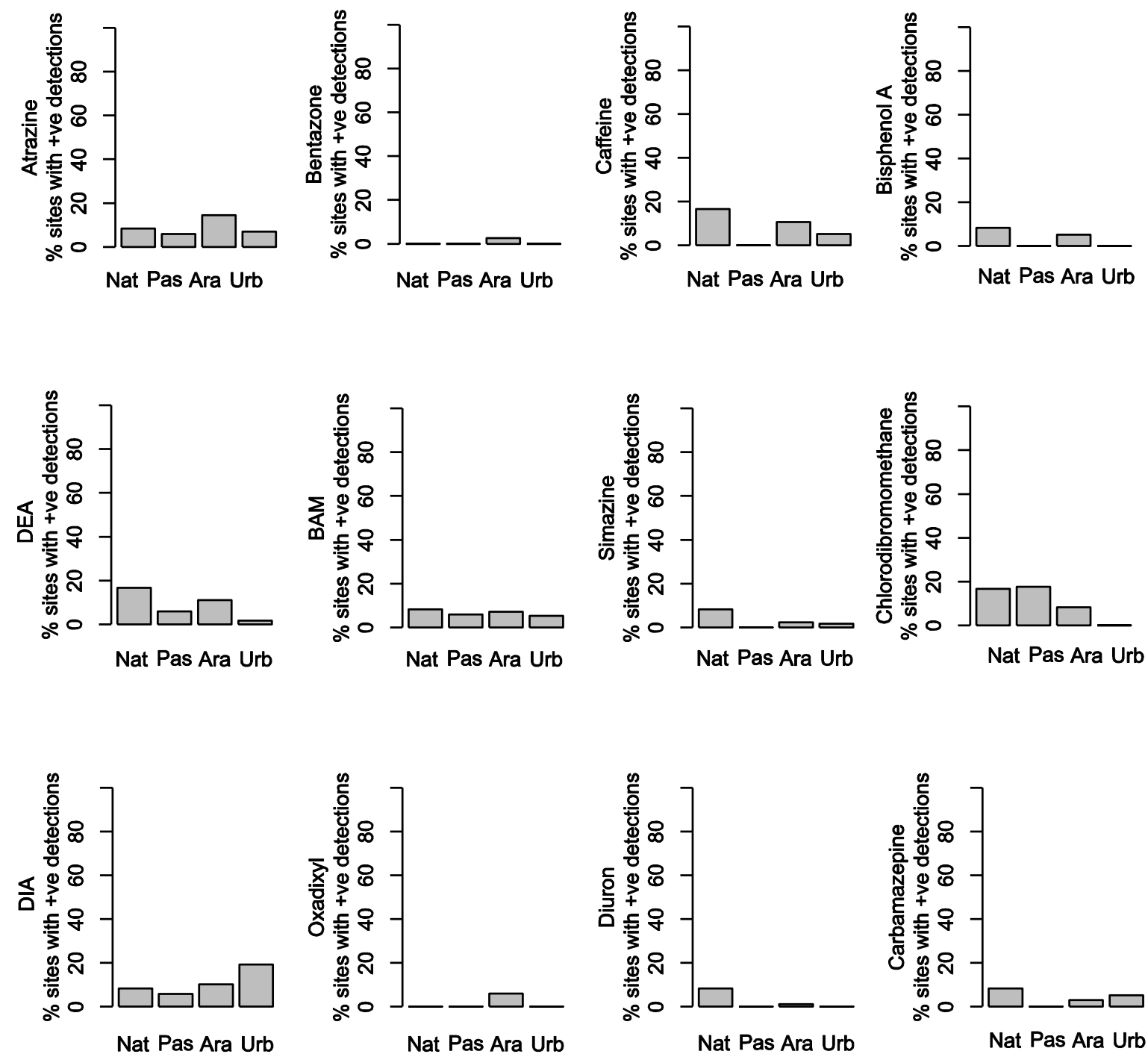

Fig. S4 Comparison of selected microorganic compounds $(\mu \mathrm{g} / \mathrm{L})$ in chalk by land use category 

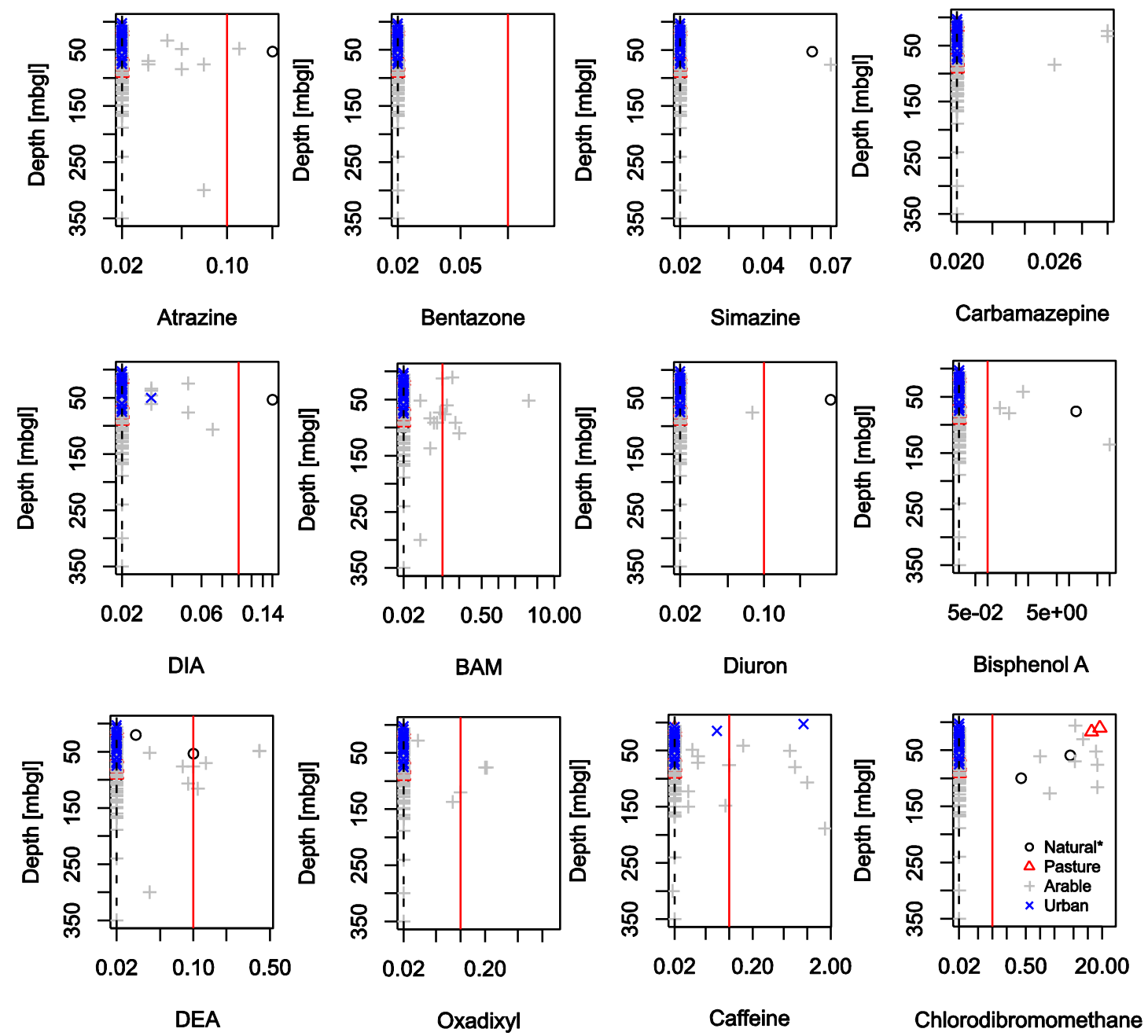

Fig. S5 Comparison of selected microorganic compounds $(\mu \mathrm{g} / \mathrm{L})$ in chalk by well depth 


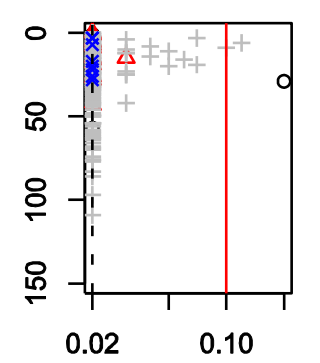

Atrazine
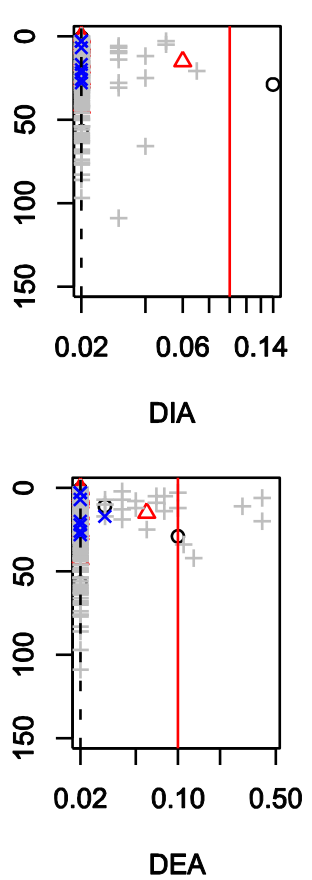

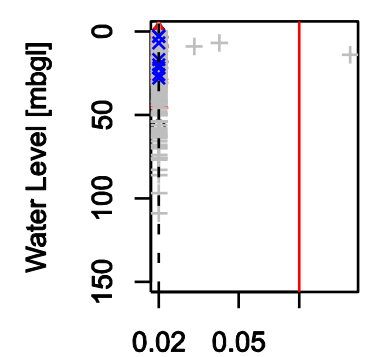

Bentazone
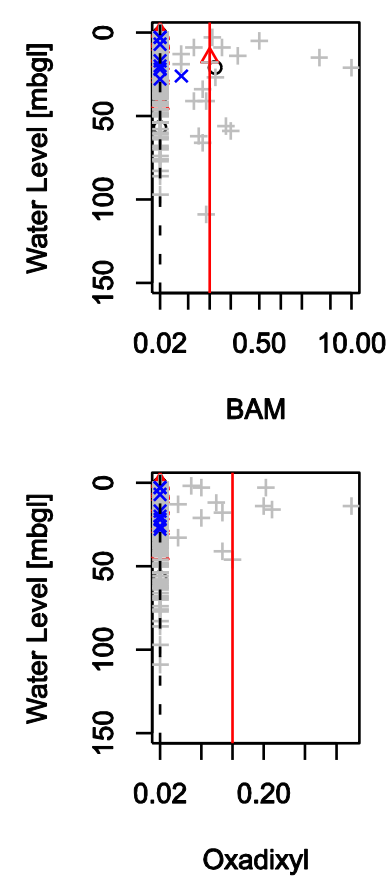
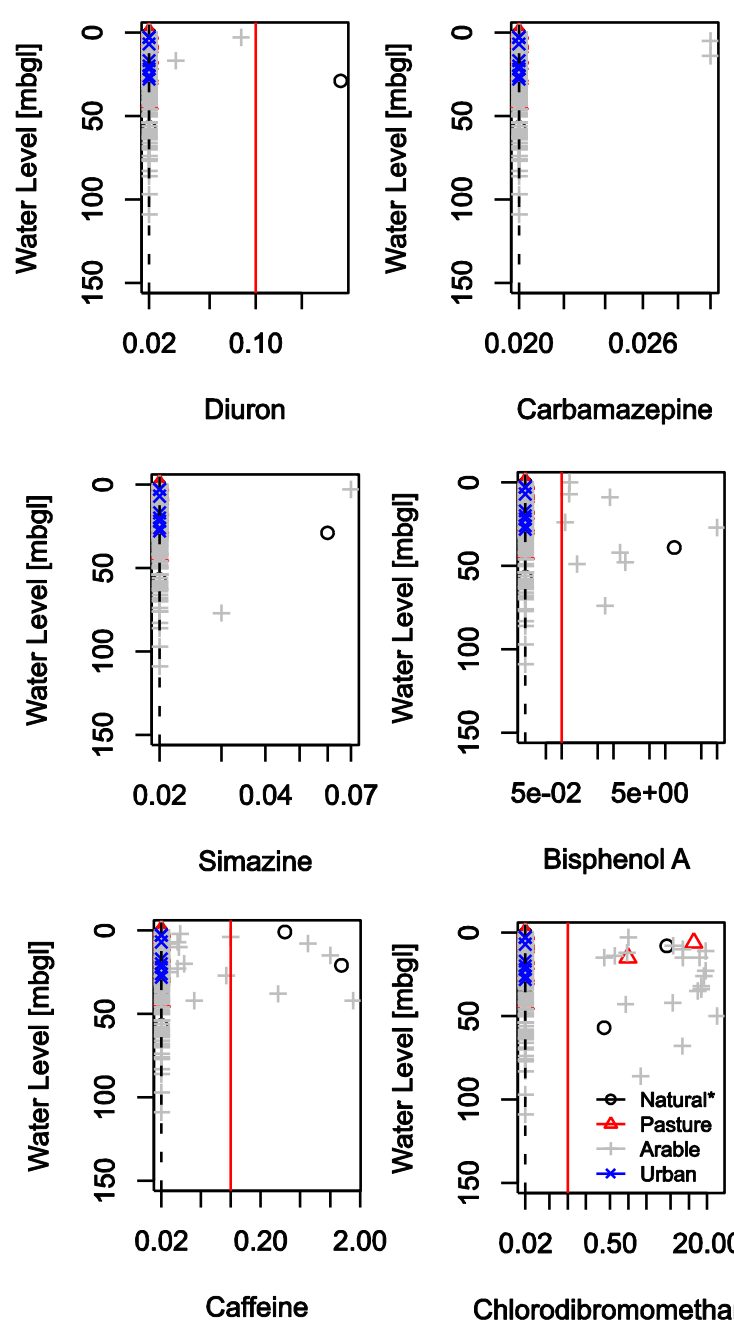

Fig. S6 Comparison of selected microorganic compounds $(\mu \mathrm{g} / \mathrm{L})$ in chalk by water level 